\title{
Risk Factors for Oral Changes in Children with Epilepsy - Informative Article
}

\author{
Svetlana Jovanović1, Ivanka Gajić1, Vlada Radivojević2 \\ 'Department of Public Health, School of Dentistry, University of Belgrade, Belgrade, Serbia; \\ 2Department for Epilepsy, Institute for Mental Health, Belgrade, Serbia
}

\begin{abstract}
Summary
Epilepsy is the most common neurological disorder in people of all ages. Based on the data regarding the prevalence of epilepsy in other countries, about 12,000 individuals under the age of 18 are estimated to suffer from active epilepsy. Children with epilepsy are a high risk group for oral diseases primarily due to psychiatric and psycho-social consequences of the primary disorder as well as the adverse effects of anti-epileptic therapy. Due to the primary disorder, children with epilepsy have reduced motivation for a number of activities, reduced mental and physical abilities, neglected social contacts, more difficult adoption of knowledge, skills, positive attitudes and behaviour as well as general and oral healthcare. In children with epilepsy, there is an additional risk for oral diseases due to the adverse effects of anti-epileptic therapy such as gingival hyperplasia. Studies in other countries and in Serbia showed higher prevalence and frequency of oral diseases compared to the control group of healthy children of the same age. This paper emphasizes the need for dental educational work with children with epilepsy and their parents as well as doctors who treat the primary disorder.
\end{abstract}

Keywords: oral disease; risk factor; children with epilepsy

\section{ETIOLOGY AND INCIDENCE OF EPILEPSY}

Epilepsies are a group of symptoms and disorders with recurrent epileptic seizures. They are the result of hyperexcitability of neurons in brain hemispheres. Clinical manifestations of epileptic seizures consist of periodical and stereotypic dysfunction of consciousness, behaviour, emotions, motor behaviour, perception or senses as the result of abnormal cortical neuron discharge [1-4].

The incidence of epilepsies worldwide is usually 20-50 individuals per 100,000 people every year, whilst the prevalence is 4-10 per 1,000 [5]. According to Hauser, epilepsy is a highly prevalent disorder found in $0.5-1.5 \%$ of the whole world population [6]. In Yugoslavia, the incidence for children and adolescents under 18 was between 24.5 and 69.2 per 1,000 people in 1985 [4]. The prevalence of epilepsy in Serbia is unknown. Based on the data regarding the prevalence of epilepsy in other countries, about 60,000 people are estimated to suffer from epilepsy and from this number about 12,000 individuals under the age of 18 [7]. In developing countries average reported incidence and prevalence rates are higher than in developed countries probably due to malnutrition, consanguinity and central nervous system infections in the former countries. Epilepsy is the most common neurological disorder in people of all ages. It is very common in childhood or early adolescence as well as in individuals over 65 . Regarding the frequency of epileptic seizures, about one third of the patients have less than one seizure per year, one third has 1-12 seizures per year and one third more than one seizure per month.

The question of aetiology of epileptic crises is very complex since there is a number of hereditary (disease or predisposition) and acquired factors (vascular, neoplastic, traumatic, infectious and other) which may act separately or in conjunction (Figure 1) [5]. Epilepsies are chronic states in which various aetiological factors maintain elevated brain excitability as the basis for periodical or recurrent epileptic seizures (Figure 2) [4].

\section{CLASSIFICATION OF EPILEPSIES}

Classification of epilepsies is based on the type of seizure, age when it began, EEG pattern and joint neurological status. The identification of epileptic syndrome or disorder is important for establishing the diagnosis, treatment planning and determining aetiology.

According to aetiology, epilepsies are classified as hereditary with an identified genetic background - idiopathic epilepsies, then epilepsies based on an identified brain damage or disorder - symptomatic epilepsies and epilepsies with non-identified but suspect symptomatic aetiology - cryptogenic epilepsies [8].

The severity of epilepsies may be low, moderate and high according to Rati et al. who considered seizure frequency, type and the number of anti-epileptic drugs and their adverse effects. According to seizure frequency in the previous year, these authors classified seizure control as good, moderate and poor [9].

In our country adopted is the World Health Organisation classification of epilepsies published in the Tenth Revision of the International Classification of Diseases (ICD-10) [10] brought into existence in 1993 and implemented in Serbia as of January 1, 1997. 


\section{EFFECTS OF ANTI-EPILEPTIC DRUGS ON MOUTH AND TEETH}

In controlled studies, the frequency of adverse effects of anti-epileptic drugs with mild to moderate intensity is rare (in $0.1-1 \%$ of children) or very rare (less than $0.1 \%$ of children) [11]. The most commonly used drugs in the treatment of epilepsies in children are carbamazepine, valproates, phenytoin, phenobarbiton, lamotrigine and gabapentin [11]

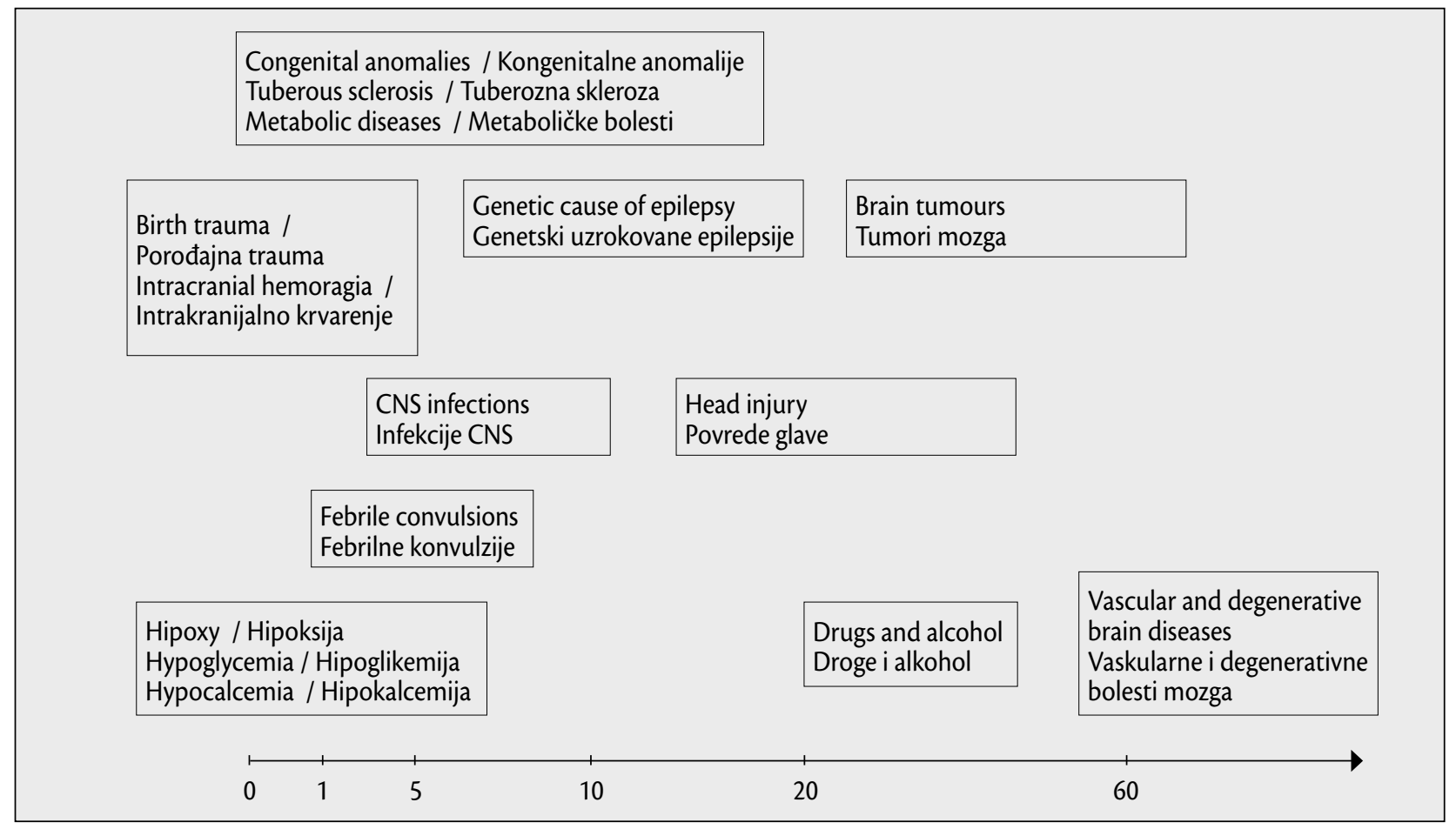

Figure 1. Aetilogy of epilepsies according to age

Shema 1. Uzroci epilepsija po godinama starosti

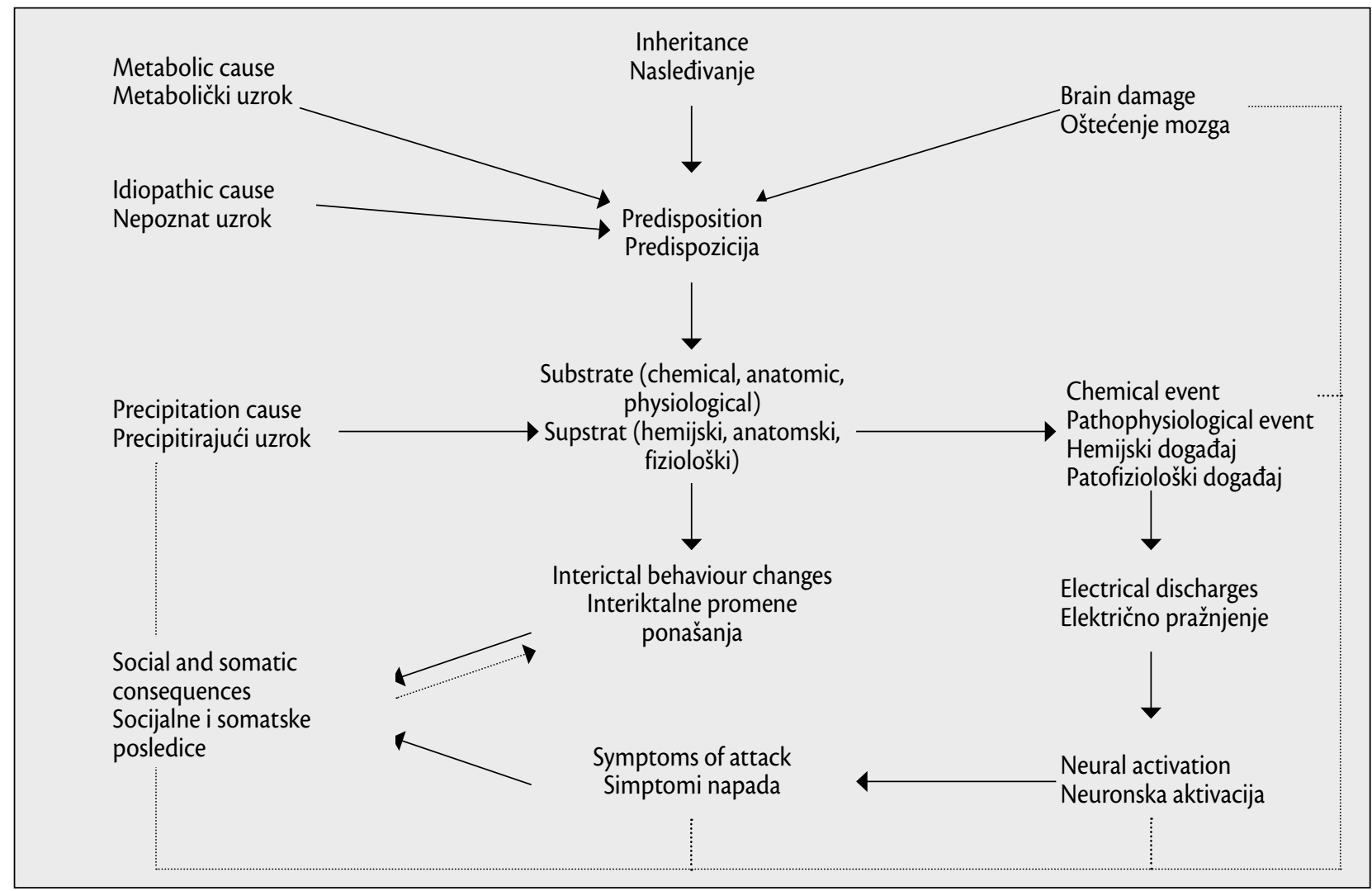

Figure 2. Interactions of bio-psycho-social factors in the development of epileptic seizures

Shema 2. Interakcije biopsihosocijalnih faktora u nastanku epileptičnih napada 
Nowadays, it is known that about $3 \%$ of the patients taking carbamazepine have gastrointestinal adverse effects and fewer patients have dry mouth and pharynx, stomatitis or glossitis whilst gingivitis was described as a rare case [1].

Gingival hyperplasia was the first reported and, at the same time, the most well-known toxic effect of phenytoin [12]. Between $13 \%$ and $50 \%$ of the patients are estimated to suffer from this effect depending on age, oral hygiene and dosage [1]. It is most common during the first 2-3 months from the beginning of the treatment and progresses during the next 12 months. Younger patients and those with poor oral hygiene and higher medication dosage are more likely to experience this effect [13]. Besides gingival hyperplasia, children taking phenytoin may have smaller teeth, retarded eruption of deciduous and permanent teeth and root resorption.

It is suggested that gingival hyperplasia may be reduced to minimum but not eliminated by avoiding local gingival irritants, maintaining good oral hygiene and regular periodontal check-ups [14]. The mechanism of this adverse effect is the change in fibroblast function which results in the proliferation of gingival connective tissue (collagen). Joint infiltration of collagen and inflammatory cells that contributes to tissue proliferation is primarily due to dental plaque [15]. Upon the discontinuation of phenytoin therapy, gingival hyperplasia ceases gradually within 3 to 6 months.

Clonazepam may result in coated tongue, xerostomia, gingival hypersensitivity and hypersalivation. Etukcimid may result in gingival hypertrophy and tongue oedema. Phenobarbiton and valproates have no reported adverse effects on mouth and teeth.

The adverse effects of new anti-epileptic drugs are mainly very rare. Gabapentin may lead to glossitis, gingival bleeding, stomatitis and hypersalivation. Seldom may oral ulcers occur as well as tooth discoloration and salivary gland enlargement. Gingivitis, hypersalivation and oral ulcers are rare adverse effects of lamotrigine which may very rarely lead to glossitis, gingival bleeding and hyperplasia, stomatitis and tongue oedema. Topiramate may result in glossitis, gingival hyperplasia and stomatitis and very rarely tongue oedema. Tiagabin may frequently trigger gingivitis and stomatitis and rarely oral ulcers, glossitis, gingival hyperplasia, hypersalivation, periodontal abscesses, caries and ulcerative stomatitis. Hypersalivation is rare in vigabatrin. Levetiracetam has no reported adverse effects on mouth and teeth $[16,17,18]$.

\section{EFFECT OF PSYCHO-SOCIAL AND PSYCHIATRIC ASPECTS OF EPILEPSY ON ORAL HEALTH}

Epilepsy is a social as well as medical disorder [1]. Epileptic seizures are often not the most difficult part for the patient and but are the joint psychiatric and psycho-social consequences instead [19]. Higher incidence of psychiatric and psychological disorders has been reported in these patients such as affective disorders (depression), personal and behavioural disorders which leads to oral health neglectance [20].
Patients with epilepsy have frequent psycho-social problems such as unemployment, social stigmatisation and discrimination, reduced social contacts, low selfesteem and poverty [5]. Research has shown that the aforementioned factors even in healthy individuals and particularly in patients with epilepsy may lead to poor oral health.

In children especially during the primary personal socialisation, epilepsy may interfere with all aspects of social adjustment with significant consequences on learning skills, behaviour, personal development and acquisition of social skills for future life [5]. All these factors affect knowledge, habits, attitudes and behaviour related to oral health which is poorer in such children compared to their healthy peers.

Insufficiently or inadequately educated parents sometimes find it very hard to accept the diagnosis of epilepsy and have negative and rejecting attitudes towards their child, believing that epilepsy is close to mental disorders or embarrassment for the family, so they neglect their child's oral health. Sometimes, parents go to the other extreme and have an overprotective attitude with unnecessary restrictions of normal activities [4]. They take the primary disorder very seriously focusing their attention to it and neglect oral health of their child. Furthermore, they pay insufficient attention to oral hygiene and regular dental visits. Both attitudes have an interfering effect on child's social development due to the imposed restrictions related to social contacts with other children and outdoor activities or due to the child's wrong self-impression. All this results in insufficient self-care and neglected social contacts which would serve as a source of information and role model for acquiring life skills [2].

\section{ORAL CHANGES IN CHILDREN WITH EPILEPSY}

Children with epilepsy are a high risk group for oral diseases. Research has shown higher prevalence and frequency of oral diseases in such children compared to their healthy peers $[21,22,23]$. In children with epilepsy, there are additional factors which deteriorate their health. Periodontal studies have shown high incidence and prevalence of periodontal disease in children with epilepsy [21,22]. Higher gingival indices have been reported in children taking antiepileptic drugs than in healthy children.

Studies in our country have also shown higher percentage of caries, extracted teeth and less filled teeth in such children as well as higher gingival and plaque indices compared to healthy children. Periodontal diseases have been found in $96 \%$ of children with epilepsy and $66 \%$ of healthy children. Among periodontal diseases, gingivitis is most common, in $86 \%$, and periodontal disease in $10 \%$ of children with epilepsy. Gingivitis has been detected in $66 \%$ of healthy children. Catarrhal gingivitis is the most commonly diagnosed type (82\% of children with epilepsy and $64 \%$ of healthy children) whilst the hyperplastic type is characteristic for children taking valproates [24]. Another study reported that children with cerebral paralysis combined with epilepsy had poorer oral health than healthy children [25]. 
Inadequate oral hygiene is often observed in oral health studies in healthy children and adolescents with epilepsy $[14,18,22]$. Compared to healthy children, those with epilepsy have significantly higher plaque index which confirms poor oral hygiene in such children [25]. It was also reported that habits, attitudes and behaviour of children with epilepsy and their parents related to oral health were poorer than in healthy children and their parents. This can be explained primarily by the fact that parents of children with epilepsy have unreal judgements and behaviour related to oral health than parents of healthy children. Children with epilepsy brush their teeth less frequently and for a shorter time than healthy children. Inadequate brushing technique was reported to be more frequent in children with epilepsy than in healthy children [26].

\section{FUTURE GUIDELINES}

Dental healthcare is enabled by modern comprehensive knowledge of the two important and widespread diseases: caries and periodontal disease. It has improved preventive planning, water fluoridation and individual training for maintaining oral hygiene. Despite all this, certain categories of patients, such as those with epilepsy, remain a problem in dental healthcare.

From the standpoint of routine dental healthcare of such patients, care must be taken towards possible seizures during interventions as well as the adverse effects of antiepileptic drugs (gingival hyperplasia, coagulation disorder, sleepiness etc.). From the preventive standpoint, advice and training for adequate oral hygiene is more difficult to implement with such patients, mostly because both the patient and doctor focus their attention to the primary neurological disorder or because there is reduced motivation mental and physical capabilities due to the illness or anti-epileptic therapy [2].

Focused dental educational work with children with epilepsy is of great importance for the improvement of their oral health. This programme should be organised with patients, their parents and doctors who treat the primary disorder according to the specific protocol based on the principle of multidisciplinary and comprehensive approach. Particular attention should be focused on adequate oral hygiene and regular dental check-ups.

\section{REFERENCES}

1. Wyllie E, editor. The Treatment of Epilepsy: Principles and Practice. $2^{\text {nd }}$ ed. Baltimore: Williams \& Wilkins; 1997.

2. Laidlaw J, editor. A Textbook of Epilepsy. $4^{\text {th }}$ ed. Edinburgh: Churchill Livingstone; 1993.

3. Marjanović B, Lević Z. Epilepsije i epileptični sindromi. Beograd: Zavod za udžbenike i nastavna sredstva; 1997.

4. Martinović Ž. Epilepsije. Gornji Milanovac: Dečje novine; 1997.

5. Appleton R, Baker G, Chadwick D, Smith D. Epilepsy. $3^{\text {rd }}$ ed. London: Martin Dunitz; 1995.

6. Hauser WA, Annegers JF, Rocca WA. Descriptive epidemiology of epilepsy: contributions of population-based studies from Rochester, Minnesota. Mayo Clin Proc. 1996; 71:576-86.
7. Institut za javno zdravlje Srbije „Dr Milan Jovanović Batut“. Statistički godišnjak Republike Srbije 2006. Beograd; 2007.

8. Commission on Epidemiology and Prognosis, International League Against Epilepsy. Guidelines for Epidemiological Studies on Epilepsy. Epilepsia. 1993; 34(4):592-6.

9. Raty LKA, Soderfeldt BA, Larsson G, Larson BMW. The relationship between illness severity, sociodemographic factors, general self-concept, and illness-specific attitude in Swedish adolescents with epilepsy. Seizure. 2004; 13:357-82.

10. Svetska zdravstvena organizacija. Međunarodna klasifikacija bolesti MKB-10. Beograd: Savremena administracija; 1996.

11. Feely M. Fortnightly review: drug treatment of epilepsy. Br Med J. 1999; 318(7176):106-9.

12. Levy RH, Mattson RH, Meldrum BS, editors. Antiepiletic Drugs. $4^{\text {th }}$ ed. New York: Raven Press; 1995.

13. Casetta I, Granieri E, Desiderá M, Monetti VC, Tola MR, Paolino $E$, et al. Phenytoin-induced gingival overgrowth: a communitybased cross-sectional study in Ferrara, Italy. Neuroepidemiology. 1997; 16(6):296-303.

14. Hall EE. Prevention and treatment considerations in patients with drug-induced gingival enlargement. Curr Opin Periodontol. 1997; 4:59-63.

15. Brunet L, Miranda J, Farre M, Berini L, Mendieta C. Gingival enlargement induced by drugs. Drug Saf. 1996; 15(3):219-31.

16. Sander JW. The use of antiepileptic drugs - principles and practice. Epilepsia. 2004; 45(6):28-34

17. Backman N, Holm AK, Hanstrom L, Blomquist HK, Heijbel J, Safstrom G. Folate treatment of diphenylhydantoin-induced gingival hyperplasia. Scand I Dent Res. 1989; 97(3):222-32.

18. Kamali F, McLaughlin WS, Seymour RA. The effect of multiple anticonvulsant therapy on the expression of phenytoin-induced gingival overgrowth. J Clin Periodontol. 1999; 26(12):802-5.

19. Trimble MR, editor. Chronic Epilepsy, its Prognosis and Management. Chichester: John Wiley \& Sons; 1989.

20. Friedlander AH, Cummings JL. Temporal lobe epilepsy: its association with psychiatric impairment and appropriate dental management. Oral Surg Oral Med Oral Pathol. 1989; 68(3):288-92.

21. Hassell TM, Burtner AP, McNeal D, Smith RG. Oral problems and genetic aspects of individuals with epilepsy. Periodontol 2000. 1994; 6:68-78.

22. Ogunbodede EO, Adamolekun B, Akintomide AO. Oral health and dental treatment needs in Nigerian patients with epilepsy. Epilepsia. 1998; 39(6):590-4.

23. Svatun B, Gjermo P. Oral hygiene, periodontal health and need for periodontal treatment among institutionalized mentally subnormal persons in Norway. Acta Odontol Scand. 1978; 36:89-95.

24. Radivojević-Jovanović S. Prevencija oralnih manifestacija kod dece obolele od epilepsije [magistarska teza]. Beograd: Stomatološki fakultet Univerziteta u Beogradu; 2000.

25. Nikodijević-Latinović A. Kraniofacijalna morfologija dece obolele od cerebralne paralize [doktorska teza]. Beograd: Stomatološki fakultet Univerziteta u Beogradu; 2003.

26. Jovanović S, Gajić I. Navike, stavovi i ponašanje dece s epilepsijom u odnosu na zdravlje usta i zuba. Srp Arh Celok Lek. 2007; 135(3-4):167-73.

\author{
Address for correpospondence \\ Svetlana Jovanović \\ Stomatološki fakultet \\ Institutski predmeti, Javno zdravlje \\ Dr Subotića 1, 11000 Beograd \\ Srbija \\ Tel.: +381 (0)112657830 \\ Email: svetlanajr@ptt.rs
}




\title{
Faktori rizika promena stanja usta i zuba dece obolele od epilepsije - informativni rad
}

\author{
Svetlana Jovanović1, Ivanka Gajić1, Vlada Radivojević ${ }^{2}$ \\ ${ }^{1}$ Institutski predmeti, Javno zdravlje, Stomatološki fakultet, Univerzitet u Beogradu, Beograd, Srbija; \\ ${ }^{2}$ Odsek za epilepsije, Institut za mentalno zdravlje, Beograd, Srbija
}

\begin{abstract}
KRATAK SADRŽAJ
Epilepsija je najčešći neurološki poremećaj koji pogađa ljude svih uzrasta. Na osnovu podataka o prevalenciji epilepsije u drugim zemljama, procenjuje se da u Srbiji oko 12.000 dece i omladine mlađe od 18 godina boluje od aktivne epilepsije. Deca obolela od epilepsije predstavljaju grupu visokog rizika za oralna oboljenja, pre svega zbog psihijatrijskih i psihosocijalnih posledica osnovne bolesti, ali i zbog neželjenih dejstava antiepileptične terapije. Zbog osnovne bolesti, kod dece s epilepsijom smanjena je motivacija za bavljenjem mnogim aktivnostima, smanjuju im se mentalne i fizičke sposobnosti, zanemaruju socijalni kontakti, otežano im je usvajanje znanja i veština, pozitivnih stavova i ponašanja, a time i briga za sopstveno opšte i oralno zdravlje. Kod dece s epilepsijom postoji i dodatni rizik od razvoja oralnih oboljenja zbog neželjenog dejstva antiepileptične terapije, koja loše utiče na stanje usta i zuba, najčešće u vidu hiperplazije gingive. Istraživanja u svetu i kod nas pokazala su da među ovom decom postoji veća rasprostranjenost i učestalost oralnih oboljenja nego kod zdrave dece istog uzrasta. Istaknuta je potreba za ciljnim stomatološkim zdravstvenovaspitnim radom sa decom obolelom od epilepsije i njihovim roditeljima, kao i s lekarima koji leče osnovno oboljenje.
\end{abstract}

Ključne reči: oboljenja usta i zuba; faktori rizika; deca; epilepsija

\section{ETIOLOGIJA I RASPROSTRANJENOST EPILEPSIJA}

Epilepsije su grupa sindroma i bolesti u kojima se javljaju ponavljajući epileptični napadi. Posledica su hiperekscitabilnosti neurona moždanih hemisfera. Klinička ispoljavanja epileptičnih napada sastoje se od povremenog i stereotipnog poremećaja svesti, ponašanja, emocija, motorike, percepcije ili čula, što je rezultat poremećenog pražnjenja neurona korteksa [1-4].

Incidencija epilepsija u svetu je 20-50 bolesnika na 100.000 osoba godišnje, a prevalencija 4-10 obolelih na 1.000 stanovnika [5]. Prema proceni Hausera (Hauser) i saradnika [6], epilepsija je visokoprevalentna bolest, jer od nje boluje $0,5-1,5 \%$ stanovništva naše planete. U bivšoj Jugoslaviji incidencija za decu i omladinu mlađu od 18 godina bila je 1985 . godine $24,5-69,2$ na 1.000 stanovnika [4]. Prevalencija epilepsije u Srbiji nije poznata, ali se na osnovu podataka o prevalenciji epilepsije u drugim zemljama procenjuje da u našoj zemlji oko 60.000 osoba boluje od aktivne epilepsije, od čega su oko 12.000 deca i omladina mlađa od 18 godina [7]. U zemljama u razvoju prosek prijavljenih stopa incidencije i prevalencije je viši nego u razvijenim zemljama, što se smatra posledicom izraženijeg faktora pothranjenosti, konsangviniteta i infekcija centralnog nervnog sistema u ovim zemljama.

Epilepsija je najčešći neurološki poremećaj koji pogađa ljude svih uzrasta. Veoma često se javlja u detinjstvu ili ranoj adolescenciji, ili kod osoba starijih od 65 godina. U pogledu učestalosti epileptičnih napada, oko jedne trećine obolelih osoba ima manje od jednog napada godišnje, jedna trećina ima 1-12 napada godišnje, a jedna trećina više od jednog napada mesečno.

Pitanje etiologije epileptičnih kriza je veoma složeno, jer postoji veliki broj naslednih (nasleđena bolest ili predispozicija) $\mathrm{i}$ stečenih faktora (vaskularna, neoplastička, traumatska, infektivna i druga etiologija) koji mogu da deluju izolovano ili udruženo (Shema 1) [5]. Epilepsije su hronična stanja u kojima različiti etiološki faktori održavaju povećanu moždanu ekscitabilnost, koja je osnova za povremeno i ponavljano javljanje epileptičnih napada (Shema 2) [4].

\section{KLASIFIKACIJA EPILEPSIJA}

Klasifikacija epilepsija se zasniva na vrsti napada koji se javljaju, uzrastu u kojem je bolest počela, obrascu EEG poremećaja i udruženom neurološkom statusu. Prepoznavanje epileptičnog sindroma ili bolesti je važno zbog postavljanja prognoze, izbora lečenja i mogućnosti određivanja etiologije.

Prema etiologiji, epilepsije se dele na one koje su nasledne, odnosno koje imaju identifikovanu genetsku osnovu - idiopatske epilepsije, na epilepsije koje su posledica prepoznatog moždanog oštećenja ili oboljenja - simptomatske epilepsije, i na epilepsije za koje se pretpostavlja simptomatska etiologija, ali nije identifikovana - kriptogene epilepsije [8].

Težina epilepsije je određena kao laka, umerena i teška prema kriterijumima Ratija (Raty) i saradnika [9], koji uzimaju u obzir učestalost napada, vrstu napada, broj antiepileptičnih lekova i njihova neželjena dejstva. Uzimajući u obzir učestalost napada u toku prethodne godine, isti autori klasifikuju kontrolu napada kao dobru, delimičnu i slabu [9].

U našoj zemlji se primenjuje klasifikacija epilepsija Svetske zdravstvene organizacije, koja je objavljena u Desetoj reviziji Međunarodne klasifikacije bolesti (MKB-10) [10]. Ona je stupila na snagu 1993. godine, a kod nas se zvanično primenjuje od 1. januara 1997. godine.

\section{DEJSTVA ANTIEPILEPTIČNIH LEKOVA NA STANJE USTA I ZUBA}

U kontrolisanim studijama učestalost javljanja neželjenih dejstava antiepileptika najčešće se beleži retko (kod 0,1-1\% dece) ili veoma retko (manje od $0,1 \%$ dece), sa blagim do umerenim intenzitetom izraženosti [11]. Najčešće korišćeni medikamenti u lečenju epilepsija kod dece su karbamazepin, valproati, fenitoin, fenobarbiton, lamotrigin i gabapentin [11].

Danas se zna da oko 3\% bolesnika koji uzimaju karbamazepin ima gastrointestinalne neželjene efekte, a kod manjeg broja 
ovih bolesnika mogu se javiti suvoća usta i ždrela, stomatitis ili glositis, dok je gingivitis opisan kao izolovani slučaj [1].

Hiperplazija gingive je prvi opisani a istovremeno i najpoznatiji toksični efekat fenitoina [12]. Bolesnika kod kojih se javlja ovaj neželjeni efekat ima između 13\% i 50\% u zavisnosti od uzrasta, stepena oralne higijene i doziranja leka [1]. Obično se javlja u prva dva-tri meseca uzimanja terapije i progredira $\mathrm{u}$ narednih 12 meseci. Kod bolesnika mlađeg uzrasta, onih s lošijom oralnom higijenom i onih koji primaju veće doze ovoga leka mogućnosti za razvoj ovog toksičnog efekta su veće [13]. Osim hiperplazije gingive, kod dece koja primaju fenitoin uočeni su pojava manjih zuba, zakasnelo nicanje mlečnih i stalnih zuba i resorpcija korenova. Utvrđeno je da se hiperplazija gingive kod osoba obolelih od epilepsije može svesti na najmanju meru - mada ne i eliminisati - izbegavanjem supstanci koje su lokalni iritansi za gingivu, održavanjem oralne higijene na visokom nivou i redovnom kontrolom parodoncijuma [14]. Mehanizam nastanka ovog toksičnog dejstva fenitoina je promena funkcije fibroblasta koja izaziva proliferaciju gingivnog vezivnog tkiva (kolagena), dok udružena infiltracija zapaljenjskim ćelijama, koja doprinosi bujanju tkiva, najčešće nastaje usled dentalnog plaka [15]. Po obustavljanju lečenja fenitoinom hiperplazija gingive se postepeno povlači za tri do šest meseci.

Klonazepam može da dovede do pojave obloženog jezika, suvoće usta, bolnosti desni i hipersalivacije. Etukcimid može da izazove hipertrofiju desni i edem jezika. Fenobarbiton i valproati, koliko je poznato, nemaju neželjenih dejstava na stanje usta i zuba.

Neželjena dejstva novih antiepileptika su uglavnom veoma retka. Kod gabapentina retko se javljaju glositis, krvarenje iz desni, stomatitis i hipersalivacija. Veoma retko se javljaju oralne ulceracije, diskoloracija zuba i uvećanje pljuvačnih žlezda. Gingivitis, hipersalivacija i ulceracija usne duplje je retko neželjeno dejstvo i kod primene lamotrigina, a može veoma retko da izazove glositis, krvarenje iz desni, hiperplaziju desni, stomatitis i edem jezika. Topiramat može retko da izazove glositis, hiperplaziju gingive i stomatitis, a veoma retko se javlja edem jezika. Tiagabin može često da dovede do gingivitisa i stomatitisa. Retko uzrokuje ulceracije usne duplje, glositis, hiperplaziju desni, hipersalivaciju, periodontalni apsces, karijes zuba i ulcerativni stomatitis. Hipersalivacija se retko javlja kod vigabatrina. Levetiracetam, koliko je poznato, nema neželjenih dejstava na stanje usta i zuba $[16,17,18]$.

\section{UTICAJ PSIHOSOCIJALNIH I PSIHIJATRIJSKIH ASPEKATA EPILEPSIJE NA ORALNO ZDRAVLJE}

Epilepsija je istovremeno i socijalni i medicinski poremećaj [1]. Veoma često epileptični napadi nisu najteži deo bolesti osobe obolele od epilepsije, već su to uzročno-posledično povezane udružene psihijatrijske i psihosocijalne posledice [19]. Kod ovih bolesnika zabeležena je povećana incidencija psihijatrijskih i psiholoških poremećaja, uključujući afektivne poremećaje (naročito depresiju), poremećaje ličnosti i ponašanja, što vodi zanemarivanju brige o oralnom zdravlju [20]. Takođe se uočavaju psihosocijalni problemi, kao što su nezaposlenost, socijalna stigmatizacija i diskriminacija, sužavanje socijalnih kontakata, nizak nivo samopoštovanja i siromaštvo [5]. Istraživanja su pokazala da nabrojani faktori i kod zdravih, a posebno kod osoba obolelih od epilepsije, značajno doprinose lošijem oralnom zdravlju.

Kod dece, naročito u periodu primarne socijalizacije ličnosti, epilepsija remeti sve aspekte socijalnog prilagođavanja, sa značajnim posledicama na usvajanje školskog znanja, ponašanje, razvoj ličnosti i sticanje socijalnih veština neophodnih za kasniji život [5]. Svi ovi činioci utiču na to da su znanja, navike, stavovi i ponašanja u vezi s oralnim zdravljem kod ove dece znatno lošiji nego kod njihovih zdravih vršnjaka.

Nedovoljno ili neadekvatno zdravstveno prosvećeni roditelji obolelog deteta ponekad teško prihvataju dijagnozu epilepsije i zauzimaju negativan i odbijajući stav prema detetu, verujući da je epilepsija nešto blisko duševnim bolestima ili nešto što sramoti porodicu, te zbog svega ovoga zanemaruju oralno zdravlje svoga deteta. Nekada roditelji idu u drugu krajnost i pokazuju preterano zaštitnički stav s nepotrebnim ograničenjima normalnih aktivnosti deteta [4]. Osnovno oboljenje shvataju veoma ozbiljno i na njega usmeravaju najveću pažnju, zbog čega zanemaruju oboljenja usta i zuba svoga deteta. Takođe, zapostavljaju održavanje oralne higijene deteta i redovne posete stomatologu. Oba stava ometaju socijalni razvoj deteta usled nametnutih zabrana u vezi s kontaktom sa vršnjacima i drugim aktivnostima van kuće, ili usled toga što i samo dete ima pogrešnu sliku o sebi kao nekom manje vrednom ili manje sposobnom. Sve ovo dovodi do toga da obolelo dete ne vodi dovoljno brigu o sebi i zanemaruje socijalne kontakte kao izvor informacija i model za usvajanje životnih veština [2].

\section{PROMENE USTA I ZUBA DECE OBOLELE OD EPILEPSIJE}

Deca obolela od epilepsije su posebna grupa kod koje je rizik od razvoja oboljenja usta i zuba visok. Istraživanja u svetu su pokazala da je kod ove dece veća rasprostranjenost i učestalost oboljenja usta i zuba nego kod njihovih zdravih vršnjaka, jer se kod njih, osim faktora rizika koji postoje i kod zdrave dece, javljaju i dodatni činioci koji narušavaju njihovo oralno zdravlje $[21,22,23]$. Istraživanja oboljenja parodoncijuma dece s epilepsijom takođe pokazuju visoku stopu incidencije i prevalencije ovih oboljenja [21,22]. Kod dece s epilepsijom koja primaju antiepileptičnu terapiju uočene su veće vrednosti gingivnog indeksa nego kod njihovih zdravih vršnjaka.

Istraživanja izvedena kod nas takođe su pokazala da deca obolela od epilepsije, u odnosu na zdravu decu, imaju veći procenat nesaniranih karijesnih i ekstrahovanih zuba, manji procenat plombiranih zuba, veći prosečan broj sekstantâ s oboljenjem parodoncijuma i veće vrednosti gingivnog indeksa i plakindeksa. Oboljenja parodoncijuma su utvrđena kod $96 \%$ dece s epilepsijom i $66 \%$ zdrave dece. U strukturi oboljenja parodoncijuma gingivitisi su zastupljeni kod $86 \%$ dece s epilepsijom i $66 \%$ zdrave dece, dok je parodontopatija dijagnostikovana kod $10 \%$ bolesnika s epilepsijom. U obe grupe dece najčešće je dijagnostikovan kataralni gingivitis ( $82 \%$ obolele i $64 \%$ zdrave dece), dok je hiperplastični oblik zabeležen samo kod dva obolela deteta koja su lečena valproatom [24]. U drugom istraživanju je utvrđeno da deca obolela od cerebralne paralize koja su imala i pridruženu epilepsiju imaju lošije stanje oralnog zdravlja nego njihovi zdravi vršnjaci [25].

Neadekvatna oralna higijena ispitanika je često ustanovljena u studijama oralnog zdravlja dece i adolescenata s epilepsijom 
$[14,18,22]$. U odnosu na zdravu decu, kod dece obolele od epilepsije beleže se znatno veće vrednosti plak-indeksa, što govori o veoma niskom nivou njihove oralne higijene [25]. Takođe je uočeno da su navike, stavovi i ponašanje dece s epilepsijom i njihovih roditelja u odnosu na oralno zdravlje lošiji nego kod zdrave dece i njihovih roditelja. Ovo se prvenstveno može objasniti time što roditelji dece s epilepsijom imaju nerealne procene i ponašanje u odnosu na zdravlje usta i zuba njihove dece nego roditelji zdrave dece. Deca s epilepsijom peru zube ređe i kraće od zdrave dece, a kod većine njih zastupljena je nepravilna tehnika pranja zuba u poređenju s njihovim zdravim vršnjacima [26].

\section{BUDUĆE SMERNICE}

Stomatološka zaštita zdravih i obolelih lica olakšana je savremenim boljim shvatanjem etiologije dva važna i rasprostranjena oboljenja: karijesa i parodontalnih bolesti. Ovo saznanje je uslovilo planiranje programa prevencije, uključujući fluorizaciju vode i individualnu obuku u pogledu metoda oralne higijene.
Uprkos ovome, izvesne kategorije obolelih u populaciji, uključujući i osobe obolele od epilepsije, i dalje su problem u stomatološkom zbrinjavanju.

S aspekta rutinske stomatološke zaštite, kod ovih bolesnika mora se voditi računa o riziku za pojavu napada tokom intervencije, kao i o neželjenim dejstvima antiepileptične terapije (hiperplazija gingive, poremećaj koagulacije, pospanost i drugo). $S$ aspekta preventivnog rada, savet, uputstvo i program ispravnog održavanja oralne higijene teže je sprovesti kod pacijenata obolelih od epilepsije, najčešće zato što i pacijent i lekar veću pažnju posvećuju neurološkom oboljenju, ili zato što postoji smanjenje motivacije, mentalnih i fizičkih sposobnosti usled bolesti i primanja antiepileptika [2].

U unapređenju oralnog zdravlja dece s epilepsijom veoma značajnu ulogu ima ciljni stomatološki zdravstvenovaspitni rad. Zdravstvenovaspitni rad treba organizovati s obolelom decom i njihovim roditeljima, kao i s lekarima koji leče osnovno oboljenje, prema posebnom protokolu definisanom na principu multidisciplinarnosti i sveobuhvatnosti. Kod dece s epilepsijom treba naročitu pažnju posvetiti pravilnom održavanju oralne higijene i redovnim preventivnim posetama stomatologu. 